\title{
Keyhole Limpet Hemocyanin IgG Antibody Measurement
}

National Cancer Institute

\section{Source}

National Cancer Institute. Keyhole Limpet Hemocyanin Ig G Antibody Measurement. NCI

Thesaurus. Code C132372.

The determination of the amount of keyhole limpet hemocyanin Ig G antibody in a biological sample. 